dr inz. Maciej Andrzejewski

dr inz. Pawet Daszkiewicz.

Instytut Pojazdów Szynowych ,TABOR”

prof. dr hab. inz. Jerzy Merkisz.

Politechnika Poznańska

dr Wtodzimierz Stawecki, prof.IPS

mgr inz. Dawid Gallas

Instytut Pojazdów Szynowych ,TABOR”

\title{
Fuel consumption and pollutants emission study of locomotives performed using a water rheostat
}

\author{
Badania zużycia paliwa i emisji zanieczyszczeń z lokomotyw z \\ wykorzystaniem opornika wodnego
}

\begin{abstract}
The article evaluates the ecological and economic indicators of selected types of locomotives used on railway lines in Poland. Rail vehicles are characterized by lower emissivity and energy consumption in comparison to the majority of currently used means of transport, which translates into higher ecological efficiency of the transport system in the scale of the whole country. The share of rail transport in overall transport in Poland and its development are limited by several aspects related to the costs of purchase and exploitation of vehicles, infrastructure and the availability of new technologies. The article presents the results of measurements carried out on 15 units of the ST44 locomotive with varying degrees of technical wear, and thus representing a wide range of technical states of this type of vehicles operated on Polish railroads. The tests have shown the impact of the degree of technical wear of a diesel locomotive both on the level of exhaust emissions as well as the fuel consumption value.
\end{abstract}

$W$ artykule dokonano oceny wskaźników ekologicznych oraz ekonomicznych wybranych typów lokomotyw uzytkowanych na liniach kolejowych w Polsce. Pojazdy szynowe charakteryzuja się niższa emisyjnościq i energochłonnościq $w$ porównaniu do większości stosowanych obecnie środków transportu, co przeklada się na większq wydajność systemu transportu w skali całego kraju. Udziat transportu szynowego w transporcie w Polsce i jego rozwój jest ograniczony kilkoma aspektami zwiqzanymi z kosztami zakupu i eksploatacji pojazdów, infrastruktury oraz dostęnościq nowych technologii. W artykule przedstawiono wyniki pomiarów przeprowadzonych na 15 lokomotywach ST44 o różnym stopniu zużycia technicznego. Tym samym reprezentowaty one duże zróżnicowanie stanów technicznych tego typu pojazdów eksploatowanych na polskich szlakach kolejowych. Badania wykazaly wpływ stopnia zużcia technicznego lokomotywy spalinowej, zarówno na poziom emisji zwiazków toksycznych, jak i wielkość zużycia paliwa.

\section{Introduction}

Despite the low exhaust emissions of rail transport compared to other modes of transport, the share of rail used in transport operations in Poland is considerably small. This translates into lower efficiency and increased emissions from the national transport system as a whole. As the costs of purchasing rail vehicles are significantly higher than for motor vehicles, the current average age of rolling stock in many cases exceeds 30 years. Most carriers treat the purchase of new rolling stock as a last resort, using cheaper solutions,

\section{Wstęp}

Pomimo niskiej emisji związków szkodliwych pochodzących $\mathrm{z}$ transportu kolejowego na tle innych środków transportu udział kolei w operacjach transportowych w Polsce jest niewielki. Przekłada się to na niską wydajność oraz podwyższoną emisyjność krajowego systemu transportu. Ponieważ koszty zakupu pojazdów szynowych są znacząco wyższe niż pojazdów samochodowych, obecny średni wiek taboru kolejowego wynosi ponad 30 lat. Większość przewoźników traktuje zakup nowego taboru szynowego jako 
such as: general overhaul, retrofitting, or modernization, which translates into a level of exhaust emissions from the locomotive that can be acceptable in Poland, despite their age. However, the main aspect in favor of using rail vehicles is fuel consumption and the directly related $\mathrm{CO}_{2}$ emissions. Despite the larger displacement volumes of locomotive engines, their $\mathrm{CO}_{2}$ emissions in grams per passenger kilometer are preferential in purely economic terms. Figure 1 presents a comparison of the value of this emission for rail, vehicle and air transport.

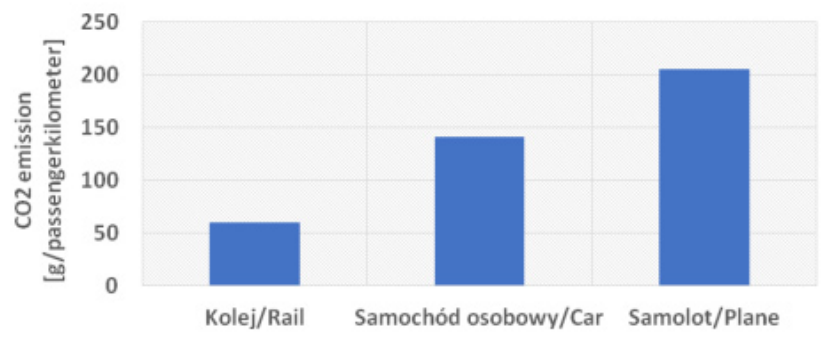

Fig. 1. Emission of $\mathrm{CO}_{2}$ per passenger per kilometer for rail transport, road transport and airplanes [1]

Rys. 1. Emisja $\mathrm{CO}_{2}$ na pasażerokilometr dla transportu szynowego, samochodowego oraz lotniczego [1]

The regression of railway transport in Poland in the last decade regarding the number of passengers transported and the distance covered was the result of political operations, where the road transport was placed as a priority and a transport model for future development. Funds allocated for motorways have significantly exceeded the value of funds transferred for maintenance and development of the railway network and infrastructure, which can be seen comparing the length of new railway lines $-34 \mathrm{~km}$, to new motorways $-2293 \mathrm{~km}$, put into operation since 2004 . Funds allocated for rail transport are not even sufficient to maintain the current railway infrastructure in a fully functional condition, but there is no possibility of its further development or major renovations without securing funds from private sources. Despite this period of stagnation and regression of the Polish railways, the possibilities and advantages of rail transport are beginning to be noticed by the national authorities. As a result, the share of rail in EU funds allocated for transport investments increased from $21.8 \%$ in $2007-$ 2013 (Figure 2a) to the level of approx. 33\% expected for 2014-2020 (Figure 2b).

Due to the above-mentioned factors, the current share of rail transport in the total weight of transported cargo in Poland remains at a relatively low level of about 13\% (Figure 3). However, it should be noted that due to increasing funding and the development and innovation of railway infrastructure, this value is currently steadily growing. ostateczność, posiłkując się tańszymi rozwiązaniami, takimi jak: naprawa główna, retrofitting lub modernizacja, co przekłada się na akceptowalny poziom emisji związków toksycznych z lokomotywy w Polsce, pomimo ich wieku. Głównym aspektem przemawiającym za zastosowaniem pojazdów szynowych jest jednak zużycie paliwa oraz bezpośrednio związana $\mathrm{z}$ nim emisja $\mathrm{CO}_{2}$. Pomimo większych objętości skokowych silników lokomotyw, ich emisja $\mathrm{CO}_{2} \mathrm{w}$ gramach na pasażerokilometr jest preferencyjna pod względem czysto ekonomicznym. Na rysunku 1 przedstawiono zestawienie wartości tej emisji dla transportu szynowego, samochodowego oraz lotniczego.

Regresja transportu kolejowego w Polsce w ostatniej dekadzie dotycząca liczby przewożonych pasażerów i pokonanego dystansu była wynikiem zabiegów politycznych, gdzie jako priorytet oraz wzorzec transportu w przyszłości postawiono transport samochodowy. Fundusze przeznaczane na autostrady znacząco przekroczyły wartość funduszy przekazywanych na utrzymanie i rozwój infrastruktury sieci kolejowej, co widać porównując długości nowych linii kolejowych $34 \mathrm{~km}$, w porównaniu do autostrad - $2293 \mathrm{~km}$, oddanych do użytku od 2004 roku. Fundusze przeznaczane na transport szynowy nie wystarczały na utrzymanie obecnej infrastruktury kolejowej w stanie zdatnym do użytku, brakuje natomiast możliwości jego dalszego rozwoju lub większych renowacji bez zabezpieczenia funduszy ze źródeł prywatnych. Pomimo tego okresu stagnacji i regresji polskiego kolejnictwa, możliwości oraz atuty transportu szynowego zaczynają być zauważane przez władze rządowe. W efekcie udział kolei w funduszach unijnych przeznaczonych na inwestycje transportowe zwiększa się z 21,8 \% w latach 2007-2013 (rys. 2a) do poziomu ok $33 \%$ na lata 2014-2020 (rys. 2b).
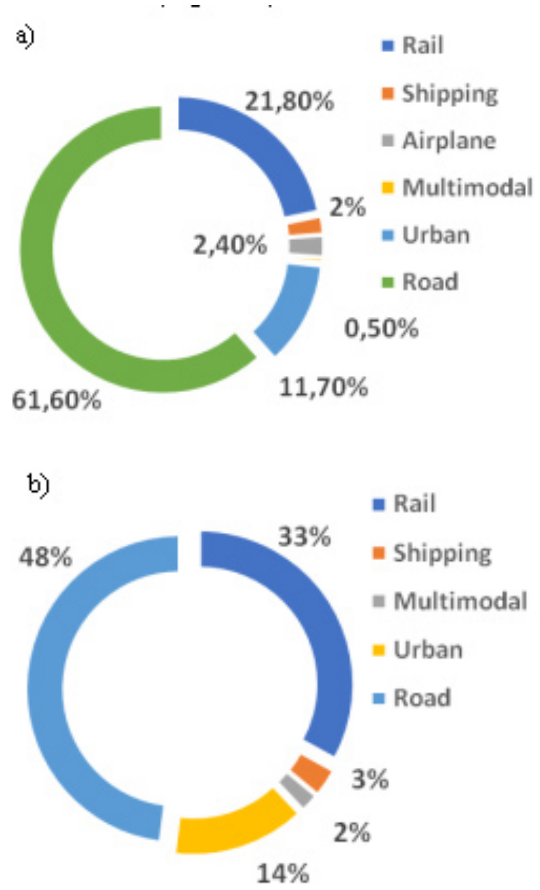

Fig 2. Share of EU funding for various types of transport investments in different sectors a) in 2007-2013, b) for 2014-2020 [1]

Rys. 2. Udział środków transportu $\mathrm{w}$ funduszach unijnych przeznaczonych na inwestycje transportowe

a) w latach 2007

2013 , b) na lata

2014-2020 [1] 


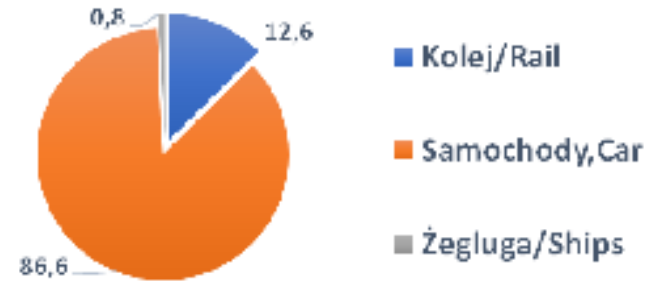

Fig. 3. Percentage share of various modes of transport in the total mass of all cargo transported in Poland [1]

Rys. 3. Procentowy udział środków transportu w całkowitej masie przewożonych ładunków w Polsce [1]

\section{Research method}

The exhaust emission tests were performed according to the NRSC (Non-Road Steady Cycle) procedure in the stationary PN-EN ISO 8178-F test conditions [2], which includes 3 engine load points. The first represents idling, for which the phase's test duration share is $60 \%$, the second point is $50 \%$ of the maximum load with a $15 \%$ phase test duration share and the third measuring point includes the maximum load and the test duration share is $25 \%$ (Figure 4 ).

The tests were carried out on a stationary vehicle test track section where the locomotive was loaded using a water resistor to simulate operating conditions. The water resistor used in the tests was a type OW6300 filled with conductive liquid, an aqueous salt solution, where two electrodes were submerged. It had a maximum continuous power dissipation of $2000 \mathrm{~kW}$, detailed operational parameters of the resistor are presented in Table 1. The operating principle of the resistor can be described using the Ohm's law.

$$
\mathrm{U}=\mathrm{IR}
$$

where: $\mathrm{U}$ - voltage [V],

I - current [A],

$\mathrm{R}$ - total device resistance $[\Omega]$.

Power dissipated on the resistor is described by:

$$
\mathrm{P}=\mathrm{I}^{2} \mathrm{R}
$$

where: $\mathrm{P}-$ power [W].

In the case of water resistor, the characteristic resistance depends on the electrolyte composition (salt concentration) of a given resistor, the distance between the electrodes in it, and by the level of submersion of electrodes. Positive electrodes are connected to the locomotive's generator via contactors placed in the high-voltage apparatus cabinet. By adjusting the electrolyte level, different resistance values can be obtained by different immersion depths of the electrode surfaces. The power dissipated in this way is converted into heat. The use of a water resistor for such measurements has been described in [3].
Z powodu wyżej wymienionych czynników obecny udział transportu szynowego $\mathrm{w}$ całkowitej masie przewożonych ładunków w Polsce pozostaje na relatywnie niskim poziomie ok. $13 \%$ (rys. 3). Należy jednak zauważyć, że dzięki większym nakładom finansowym oraz rozbudowie i renowacji infrastruktury kolejowej, wartość ta ma obecnie tendencję wzrostową.

\section{Metodyka badawcza}

Badania emisji zanieczyszczeń przeprowadzono według procedury NRSC (Non-Road Steady Cycle) w warunkach stacjonarnego testu wg PN-EN ISO 8178-F [2], który obejmuje 3 punkty obciążenia silnika. Pierwszy to bieg jałowy, dla którego udział fazy wynosi $60 \%$, drugi punkt to $50 \%$ obciążenia przy udziale fazy $15 \%$ oraz trzeci punkt pomiarowy obejmuje maksymalne obciążenie, a udział wynosi $25 \%$ (rys. $4)$.

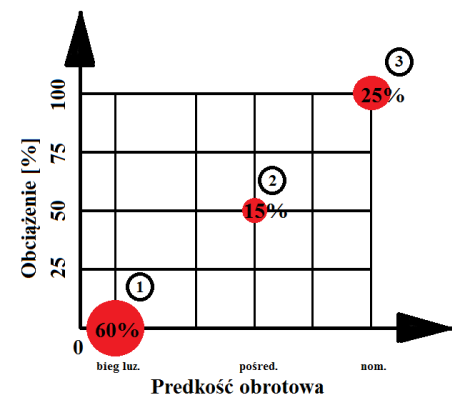

Fig. 4. The PN-EN ISO 8178 cycle $F$ test engine load histogram Rys. 4. Przebieg testu badawczego wg PN-EN ISO 8178 cykl F [5]

Badania przeprowadzono na stanowisku pomiarowym, na którym lokomotywę podczas testów obciążano za pomocą opornika wodnego. Wykorzystany w badaniach opornik wodny to typ OW6300 wypełniony cieczą przewodzącą, którą był wodny roztwór soli z zanurzonymi dwoma elektrodami o maksymalnej mocy ciagłej $2000 \mathrm{~kW}$. Szczegółowe parametry operacyjne opornika przedstawiono $\mathrm{w}$ tablicy 1 . Zasade działania opornika można opisać prawem Ohma.

$$
\mathrm{U}=\mathrm{IR}
$$

gdzie: $\mathrm{U}$ - napięcie [V],

I - natężenie prądu $[\mathrm{A}]$,

$\mathrm{R}$ - oporność urządzenia $[\Omega]$.

W przypadku opornika wodnego oporność, jaką się on charakteryzuje jest zależna od składu elektrolitu (stężenia soli) danego opornika oraz od odległości między znajdującymi się w nim elektrodami. Regulując ich odległością, przez różne głębokości zanurzenia powierzchni elektrod, uzyskać można różne wartości oporności. Uzyskana w ten sposób moc przetwarzana jest na ciepło. Zastosowanie Moc wydzieloną na oporniku opisuje wzór:

Moc wydzieloną na oporniku opisuje wzór:

$$
\mathrm{P}=\mathrm{I}^{2} \mathrm{R}
$$

gdzie: $\mathrm{P}-$ moc $[\mathrm{W}]$ opornika wodnego do tego 
Table 1. Water resistor operational parameters

Tablica 1. Parametry operacyjne opornika wodnego

\begin{tabular}{|l|c|}
\hline \multicolumn{1}{|c|}{ Parametr } & Wielkość \\
\hline Maksymalny prąd & $6300 \mathrm{~A}$ \\
\hline Prąd ciaggły bez chłodzenia elektrolitu & $1000 \mathrm{~A}$ \\
\hline Prąd ciagły z chłodzeniem elektrolitu & $2000 \mathrm{~A}$ \\
\hline Maksymalne napięcie & $1000 \mathrm{~V}$ \\
\hline Moc ciagła rozpraszana bez chłodzenia & $750 \mathrm{~kW}$ \\
\hline Moc ciaggła rozpraszana z chłodzeniem & $2000 \mathrm{~kW}$ \\
\hline
\end{tabular}

\begin{tabular}{|l|c|}
\hline \multicolumn{1}{|c|}{ Parameter } & Value \\
\hline Maximum current & $6300 \mathrm{~A}$ \\
\hline Continuous current without electrolyte cooling & $1000 \mathrm{~A}$ \\
\hline Continuous current with electrolyte cooling & $2000 \mathrm{~A}$ \\
\hline Maximum voltage & $1000 \mathrm{~V}$ \\
\hline Continuous power dissipated without cooling & $750 \mathrm{~kW}$ \\
\hline Continuous power dissipated with cooling & $2000 \mathrm{~kW}$ \\
\hline
\end{tabular}

The exhaust emissions values - the concentration of individual components in the exhaust gases - as well as the fuel consumption was determined using the Testo 360 device. Values of the measured parameters were obtained after providing a sample of exhaust gases to the mobile measuring device - a set of analyzers. For this purpose, a probe was installed mounted in the locomotive engine exhaust system (Fig.5). The parameters of the engine's operation, including the generated power, were determined from the train driver's position - i.e. from the control panel in the cabin. The tests were performed using 15 chosen units of the ST44 locomotive. The tested locomotives differed slightly with the engine type or exhaust system elements as well as performed various transport tasks, which resulted in a different degree of wear of the locomotive subsystems. Several of the tested vehicles were used for the measurement of exhaust emissions before and after the vehicle general overhaul.

\section{Measurement results and analysis}

In order to assess the impact of the locomotive engine general overhaul on its exhaust emissions, exhaust emission tests for 2 selected ST44 locomotives were performed before and after the general overhaul. The measurements, aside from the ISO $8178-\mathrm{F}$, were made for different positions of the drive controller so as to map the parameters of the real operating conditions of the locomotive. The time density for individual drive controller positions is shown in Figure 6. The obtained specific emission values from the tested locomotives engines were compared to the ORE B13 and UIC 623 standards (Figure 7).

Based on the results obtained, a significant impact of the general overhaul on the locomotive engine exhaust emission level was demonstrated. This result confirms the legitimacy of this type of repair procedures. The general overhaul which is a part of the costs covered by the carrier when purchasing a new rolling stock, makes it possible to reduce the emissivity of the locomotive to the level specified in the ORE typu badań opisane jest wielokrotnie w literaturze, np. w poz. [3].

Wielkość toksyczności spalin - stężenie poszczególnych składników w gazach wylotowych - oraz zużycie paliwa określano przy wykorzystaniu urządzenia Testo 360. Wartości oczekiwanych parametrów pozyskiwano po dostarczeniu próbki spalin do mobilnego urządzenia pomiarowego - zestawu analizatorów. Do tego celu służyła sonda zamontowana w układzie wylotowym silnika lokomotywy (rys. 5). Parametry pracy silnika, w tym jego moc użyteczna, były określane z pozycji maszynisty - panel kontrolny $\mathrm{w}$ kabinie. Badania wykonano w odniesieniu do 15 wybranych lokomotywy ST44. Wybrane lokomotywy różniły się nieznacznie elementami układów wylotowych oraz wykonywały różne prace transportowe, co powodowało różny stopień zużycia lokomotywy. Kilka z badanych obiektów przebadano pod względem emisji związków toksycznych spalin przed i po naprawie głównej.

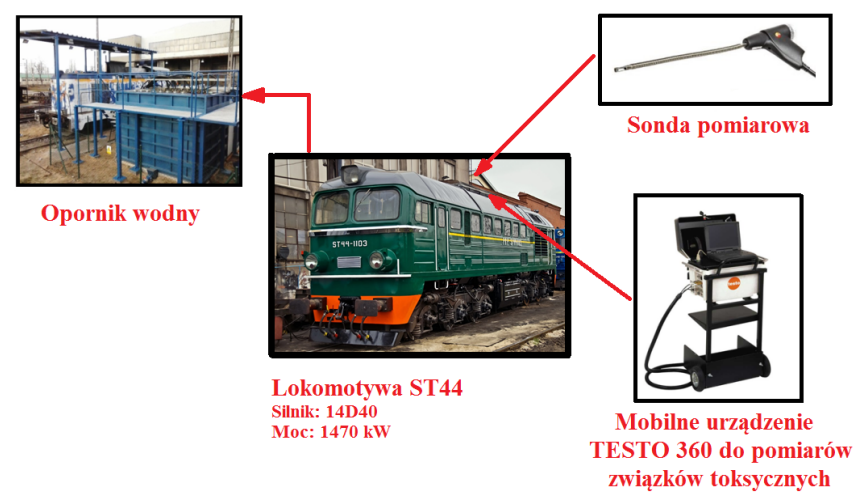

Fig. 5. An example of a test vehicle using a mobile exhaust emission measuring device connected to a water resistor

Rys. 5. Przykładowy obiekt podczas badań mobilną aparaturą do pomiarów związków toksycznych w gazach wylotowych na oporniku wodnym

\section{Wyniki pomiarów i ich analiza}

W celu dokonania oceny wpływu naprawy głównej lokomotywy na emisję spalin, wykonano badania emisji związków toksycznych dla 2 wybranych lokomotyw ST44 przed i po naprawie głównej. Pomiary wykonywano, oprócz testu wg ISO 8178-F, także przy zastosowaniu innych pozycji nastawnika jazdy tak, aby odwzorować parametry rzeczywistej eksploatacji lokomotywy. Udział czasu pracy dla poszczególnych pozycji nastawnika jazdy przedstawiono na rys. 6 . Uzyskane wartości emisji jednostkowej z silników badanych lokomotyw odniesiono do norm ORE B13 oraz UIC 623 (rys. 7).

$\mathrm{Na}$ podstawie otrzymanych wyników wykazany został znaczący wpływ naprawy głównej na poziom emisji związków toksycznych z silnika lokomotywy. Wynik ten potwierdza zasadność tego typu procedur naprawczych. Koszt naprawy głównej jest zaledwie ułamkiem kosztów, które przewoźnik ponosi przy zakupie nowego taboru. Pozwala ona zmniejszyć 
B13 (1991-1996). However, it is not possible to meet the more restrictive newer emission limits, such as the UIC 623.

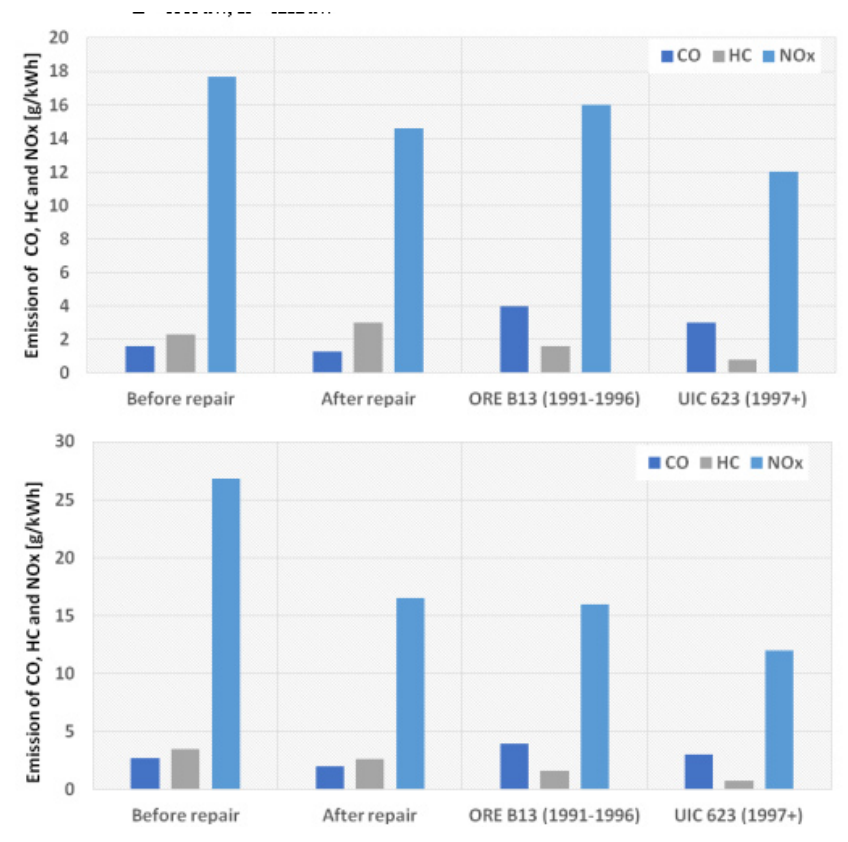

Fig. 7. Results of specific emissions values of toxic compounds for two selected ST44 locomotives before and after their general overhaul

Rys. 7. Wartości jednostkowych emisji związków toksycznych dla dwóch wybranych lokomotyw ST44 przed i po naprawie głównej

The main aspect determining the exhaust emissions during locomotives operation is their engine, in this case it was a compression-ignition engine. While new locomotives can be equipped with hybrid drives or electric motors powered with alternative fuels (such as hydrogen), the renovation of older locomotives does not allow for such extensive structural changes, however, replacing the internal combustion engine with a newer, more efficient one that emits fewer toxic compounds to the atmosphere is still possible. The effects of performing this engine switch are shown in Figure 8 , where the basic 14D40 two-stroke engine was replaced with the newer version marked 654E3B or the modern, supercharged, twelve-cylinder diesel engine $12 \mathrm{CzN} 26 / 26$ with direct injection and charger air cooler, meeting the exhaust emission requirements of the UIC 624 II standard. The potential effect of such modifications and repairs have been widely reported before, such as in [4].

Rail vehicle tests in the aspect of economic indicators were made based on the measurement of fuel consumption calculated on the basis of exhaust emission results using the carbon balance method [5]. This measurement was carried out for 15 ST44 locomotives with varying degrees of exploitation wear for the cases of maximum engine load using a water resistor and no load for idling. In order to ensure comparability of the results, all tested locomotives were equipped with the same 14D40 type combustion engine. The distribution of obtained values was in the range of up to $15 \%$ for emisyjność lokomotywy do poziomu mieszczącego się w normach ORE B13 (1991-1996). Niemożliwe okazuje się natomiast spełnienie bardziej restrykcyjnych nowszych limitów emisji, jak choćby wg UIC 623.

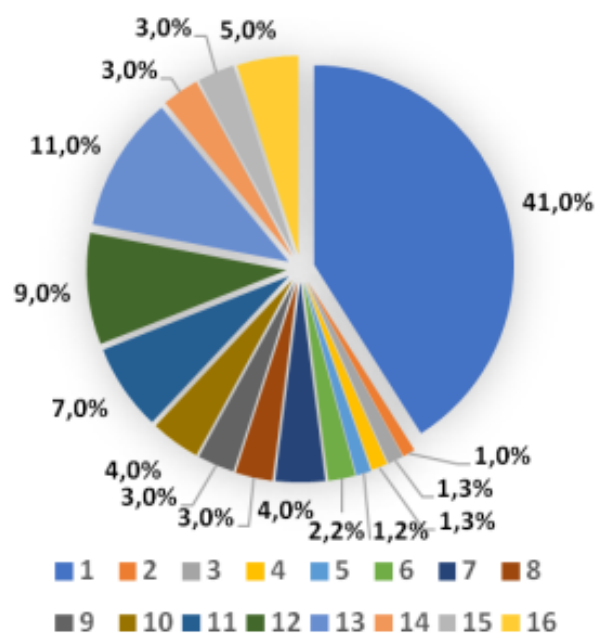

Fig. 6. Graph of the operating time density for individual positions of the drive controller. The power values denoted by these settings are as follows: $\mathbf{1}-0 \mathrm{~kW}, \mathbf{2}-40 \mathrm{~kW}, \mathbf{3}-100 \mathrm{~kW}, \mathbf{4}-200 \mathrm{~kW}, \mathbf{5}-$ $400 \mathrm{~kW}, \mathbf{6}-450 \mathrm{~kW}, 7-550 \mathrm{~kW}, \mathbf{8}-550 \mathrm{~kW}, \mathbf{9}-650 \mathrm{~kW}, \mathbf{1 0}-$ $700 \mathrm{~kW}, 11-750 \mathrm{~kW}, \mathbf{1 2}-800 \mathrm{~kW}, \mathbf{1 3}-910 \mathrm{~kW}, \mathbf{1 4}-1000 \mathrm{~kW}$, $\mathbf{1 5}-1100 \mathrm{~kW}, \mathbf{1 6}-1232 \mathrm{~kW}$

Rys. 6. Wykres udziału czasy pracy dla poszczególnych pozycji nastawnika jazdy

Wartości mocy dla tych pozycji są następujące: $1-40 \mathrm{~kW}, \mathbf{2}-100$ $\mathrm{kW}, \mathbf{3}-200 \mathrm{~kW}, \mathbf{4}-400 \mathrm{~kW}, \mathbf{5}-450 \mathrm{~kW}, \mathbf{6}-550 \mathrm{~kW}, \mathbf{7}-550$ $\mathrm{kW}, \mathbf{8}-650 \mathrm{~kW}, \mathbf{9}-700 \mathrm{~kW}, \mathbf{1 0}-750 \mathrm{~kW}, \mathbf{1 1}-800 \mathrm{~kW}, \mathbf{1 2}-$ $910 \mathrm{~kW}, \mathbf{1 3}-1000 \mathrm{~kW}, \mathbf{1 4}-1100 \mathrm{~kW}, \mathbf{1 5}-1232 \mathrm{~kW}, \mathbf{1 6}-1232$ $\mathrm{kW}$

Głównym aspektem określającym emisję związków toksycznych podczas pracy lokomotyw jest ich jednostka napędowa, w tym przypadku był to silnik o zapłonie samoczynnym. Podczas gdy nowe lokomotywy mogą być wyposażone w napędy hybrydowe lub silniki zasilane paliwami alternatywnymi (takimi jak CNG czy wodór), renowacja starszych lokomotyw nie pozwala na tak daleko idace zmiany konstrukcyjne. Jednakże dokonanie wymiany silnika spalinowego na jednostkę nowszą, bardziej sprawną i emitującą mniej związków toksycznych do atmosfery jest możliwe. Efekty takiej wymiany przedstawiono na rys. 8, gdzie porównano podstawowy dwusuwowy silnik widlasty $14 \mathrm{D} 40 \mathrm{z}$ nowszą wersją oznaczoną jako 654E3B oraz silnikiem 12CzN26/26 - dwunastocylindrowym, ZS z wtryskiem bezpośrednim, doładowanym, z chłodnicą powietrza doładowującego, spełniający wymagania $\mathrm{w}$ zakresie emisji składników toksycznych do atmosfery zgodnie z kartą UIC 624 II. Potencjalne efekty zastosowania tego typu silnika w naprawie głównej lokomotyw wykazano w poz. [4].

Badania pojazdów szynowych w aspekcie ekonomicznym wykonano na podstawie określenia zużycia paliwa przy wykorzystaniu wyników emisji związków toksycznych (za pomocą metody carbon balance) [5]. Obliczenia wykonano dla 15 lokomotyw ST44 o różnym stopniu wyeksploatowania, zarówno podczas 
fuel consumption at full load and up to $35 \%$ for operation without any load (Fig. 9).

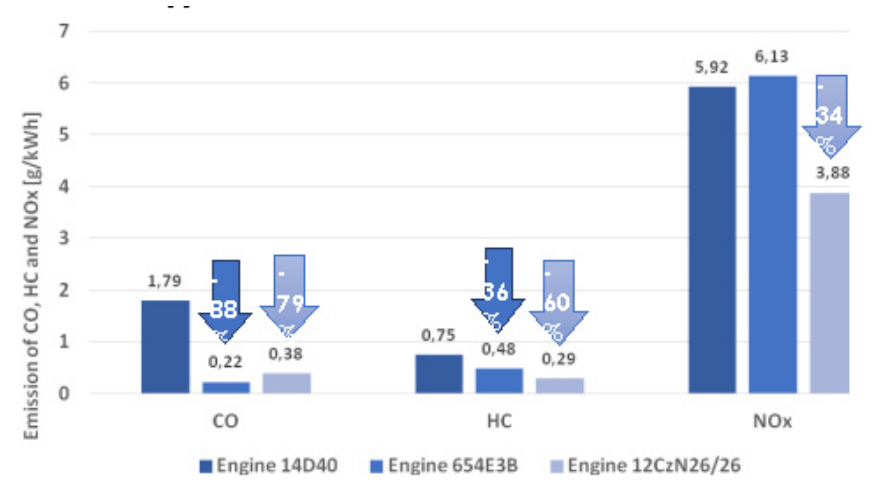

Fig. 8. Ecological indicators comparison of ST44 locomotives equipped with different engines

Rys. 8. Porównanie wskaźników ekologicznych lokomotyw typu ST44 wyposażonych w różne jednostki napędowe

\section{Conclusions}

The general overhaul of the locomotive engine leads to a noticeable reduction in the emission of all measured toxic compounds emitted. The conducted research has managed to reduce the emissivity of the tested locomotives to the level in line with the norm ORE B13 (1991-1996). However, it was not possible to meet the more restrictive new emission limits such as the UIC 623. It should be noted, however, that the aim of this type of repair is not to achieve an improvement of the locomotive's ecological indicators greater than the level required by law. The general overhaul of the engine mainly allows to improve the economic indicators of the locomotive and increase its reliability during future operations. It should be noted that the results presented in the paper indicate that it is possible to take further steps to reduce exhaust emissions from this vehicle type. Such solutions include retrofitting, that is, equipping the vehicle with an exhaust aftertreatment system that can further significantly reduce the emission of toxic compounds up to several dozen percent [6].

Out of the tested vehicles the lowest specific exhaust emissions during operation when loaded by a water resistor was registered for the $12 \mathrm{CzN} 26 / 26$ engine, achieving $79 \%$ lower $\mathrm{CO}, 60 \%$ lower $\mathrm{HC}$, and $34 \%$ lower $\mathrm{NO}_{\mathrm{x}}$ emission with respect to the traditional 14D40 engine. This indicates that replacing the engine unit with a newer one is the most economically viable alternative to the purchase of new rolling stock. The main disadvantage of this solution is the fact that not all locomotive constructions allow for this type of repair. In the case when there is no new replacement engine, which would fit in the vehicle construction and its ergonomics, engine replacement can be definitely be the more expensive option if not even completely impossible.

The performed tests also allowed to clearly present the differences in the engine fuel consumption maksymalnego obciążenia silnika z wykorzystaniem opornika wodnego, jak i bez obciążenia, dla biegu jałowego. W celu zapewnienia porównywalności wyników wszystkie badane lokomotywy wyposażone były w standardowy silnik 14D40. Rozrzut uzyskanych wartości zawierał się w zakresie do $15 \%$ dla zużycia paliwa przy pracy z pełnym obciążeniem oraz do $35 \%$ dla pracy bez obciążenia (rys. 9).

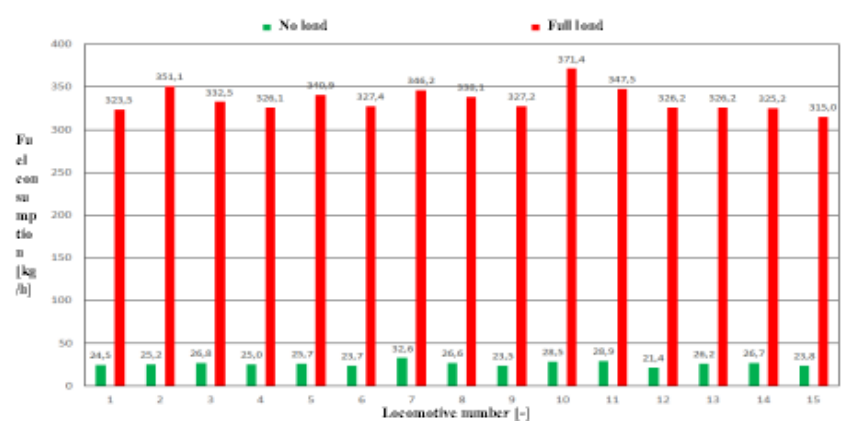

Fig. 9. Comparison of fuel consumption for ST44 locomotives measurements with engine load (14D40) and without load

Rys. 9. Porównanie zużycia paliwa dla lokomotyw typu ST44 pomiary z obciążeniem silnika (14D40) oraz bez obciążenia

\section{Wnioski}

Dokonanie naprawy głównej silnika lokomotywy powoduje zauważalne zmniejszenie emisji mierzonych związków toksycznych. W przeprowadzonych badaniach udało się zmniejszyć emisyjność testowanych lokomotyw do poziomu mieszczącego się w normie ORE B13 (1991-1996). Nie było możliwe natomiast spełnienie bardziej restrykcyjnych nowszych limitów emisji, jak UIC 623. Należy jednak zauważyć, że tego typu naprawa nie jest ukierunkowana na większą poprawę wskaźników ekologicznych lokomotywy niż poziom wymagany prawnie. Naprawa główna przede wszystkim pozwala na poprawienie wskaźników ekonomicznych lokomotywy oraz zwiększenia jej niezawodności w czasie przyszłej eksploatacji. Należy zaznaczyć, że przedstawione w pracy wyniki wskazuja, iż możliwe jest wykonanie dalszych kroków w celu zmniejszenia emisji spalin z tego typy pojazdów. Do rozwiązań takich zalicza się retrofitting, czyli doposażenie pojazdu w układ oczyszczania spalin, który potrafi w dalszym stopniu znacząco zmniejszyć emisję związków toksycznych nawet o kilkadziesiąt procent [6].

$\mathrm{Z}$ badanych pojazdów najmniejszą emisją jednostkową związków toksycznych podczas pracy na oporniku wodnym wykazał się silnik $12 \mathrm{CzN} 26 / 26$ osiagając emisję CO niższą o $79 \%$, $\mathrm{HC}$ o $60 \%$, a $\mathrm{NO}_{\mathrm{x}}$ o 34 $\% \mathrm{w}$ odniesieniu do tradycyjnego silnika 14D40. Pozwala to stwierdzić, że wymiana jednostki napędowej na nowszą jest jak najbardziej uzasadnioną alternatywą w odniesieniu do zakupu nowego taboru. Główną wadą tego rozwiązania jest fakt, że nie wszystkie konstrukcje lokomotyw umożliwiają dokonania tego typu 
values for the tested locomotives (depending on the vehicle age and technical status). The differences of fuel consumption values obtained under full engine load reached $15 \%$, while without load they reached up to $35 \%$. The fuel consumption values obtained in this way can be used as the locomotive engine's technical condition indicators. In the long-term, the difference of approx. $20 \%$ may significantly affect the operational costs of rolling stock incurred by the vehicle operator, which may contribute to speeding up the decision to repair or replace the rolling stock.

\section{Bibliography / Bibliografia}

[1] Fundacja ProKolej, http://www.prokolej.org/pl/info grafiki (dostęp $w$ dniu 04.07.2018)

[2] Pielecha J., Merkisz-Guranowska A., Andrzejewski M., Daskiewicz P., Stawecka H. Ecological aspect of using road-rail vehicles for shunting operations. Pojazdy Szynowe 2016, Nr 1, s. 1-8.

[3] Kowalski, S., Sowa, A., Classification of technical diagnostic methods used in rail vehicle repair works. Problemy Eksploatacji 2007, nr 2, s. 65-76.

[4] Stawecki W., Marciniak, Z., Pielecha I., Pielecha J. Problems of exhaust gas emission of modernized diesel locomotives operating in Poland. PTNSS-2014-106, Combustion Engines 2014, 156(1), s. 48-58.

[5] Bajerlein, M., Fuć, P., Lijewski, P., Rymaniak, L., Ziółkowski, A., Dobrzyński, M., Simulation of vehicle work in real conditions at engine test bed. PTNSS2013-SC-124, Combustion Engines 2013, R. 52, no. 3, s. 708-715, ISSN 2300-9896.

[6] Lenz, M., Powertrains and fuels for locomotives. Electro-Motive Diesel, NAFTANEXT, April 23, 2014. prac. W przypadku kiedy nie ma nowego silnika zastępczego, który wpisywałby się w ograniczenia konstrukcyjne oraz ergonomiczne, wymiana jednostki napędowej może być zdecydowanie droższa w wykonaniu lub całkowicie niemożliwa.

Podczas przeprowadzonych badań wykazano również różnice $\mathrm{w}$ wartościach zużycia paliwa przez jednostki napędowe badanych lokomotyw (w zależności od stopnia ich wyeksploatowania). Maksymalne różnice pod obciążeniem zawierały się w zakresie do $15 \%$, natomiast bez obciążenia do $35 \%$. Uzyskane w ten sposób wartości zużycia paliwa moga być wykorzystane jako wskaźniki stopnia pogorszenia stanu technicznego silnika lokomotywy. W długotrwałej eksploatacji różnica ok. $20 \%$ może znacząco wpłynąć na koszty eksploatacyjne taboru kolejowego ponoszone przez przewoźnika, co może przyczynić się do przyspieszenia decyzji o naprawie głównej bądź wymianie taboru na nowy. 